\title{
THIOCYANATE ION-SELECTIVE PVC MEMBRANE ELECTRODE
}

\author{
Mihail Revenco ${ }^{\mathrm{a} *}$, Mariana Martin, Waell Abu Dayyih ${ }^{\mathrm{b}}$ \\ ${ }^{a}$ Moldova State University, Department of Chemistry and Chemical Technology, Republic of Moldova \\ ${ }^{\mathrm{b}}$ Petra University, Faculty of Pharmacy and Medical Sciences, Amman, Jordan
}

\begin{abstract}
A potentiometric selective sensor based on trinuclear chromium(III) complex as a novel ionophore for the thiocyanate-selective electrode is reported. The sensor displays a near Nernstian slope of $57 \pm 2 \mathrm{mV}$ per decade, over a wide $\mathrm{pH}$ range $3-11$. The working concentration range of the electrode is $1 \cdot 10^{-5}-1 \cdot 10^{-1} \mathrm{~mol} / \mathrm{L}$ with a detection limit of $5 \cdot 10^{-6} \mathrm{~mol} / \mathrm{L}$. The sensor has a response time of $20 \mathrm{~s}$ and can be used for at least 6 months without any considerable fluctuation of the potential. The selectivity coefficients determined at using the fixed interference method indicate a good discriminating ability towards other anions. The prepared sensor was applied as an indicator electrode in the titration of thiocyanate with $\mathrm{Ag}^{+}$.
\end{abstract}

Keywords: thiocyanate, potentiometric sensor, titration.

\section{Introduction}

The thiocyanate ion is usually present in low concentrations in human serum, saliva, and urine as a result of the digestion of some vegetables of the genus Brassica containing glucosinolates (cabbage, turnip, kale) or by intake of thiocyanate-containing foods such as milk and cheese [1]. Higher concentration of this ion, which is a metabolic product of cyanide, arises from tobacco smoke. In this respect, the concentration level of thiocyanate in human plasma is considered to be a good probe to distinguish between smokers and non-smokers. It has been found that there is a correlation among the blood cyanide, the plasma thiocyanate, and the salivary thiocyanate [1]. Saliva of non-smokers contains thiocyanate concentrations between $0,5-2 \mathrm{mM}$ while in smokers, concentrations higher than $6 \mathrm{mM}$ can be found. Chronically elevated levels of thiocyanate in body fluids are known to be toxic and its relation to local goiter, vertigo, or unconsciousness has been pointed out. Therefore, an accurate, simple, and rapid method for the determination of thiocyanate is significant in medicine and in the life sciences. Various methods, such as spectrophotometry, Raman spectroscopy, gas chromatography, electrochemistry and potentiometry based on ion-selective electrodes (ISE) [2-11] have been reported for the determination of thiocyanate concentration in various samples. Among these methods, carrierbased ISE have emerged as one of the most promising tools for this purpose because of their unique advantages such as simplicity, speed of analysis, fast response time, low cost, wide linear range, reasonable selectivity etc. These advantages of ISE have inevitably led to the development of potentiometric sensors for many inorganic and organic species and the list of available electrodes has grown substantially over the past years.

In this work, we describe the construction and characterization of a new thiocyanate selective electrode based on a trinuclear chromium (III) complex incorporated in a poly (vinyl chloride) (PVC) membrane.

\section{Experimental}

\subsection{Reagents}

All reagents used were of analytical grade. The solutions were prepared using twice distilled water. The $\mathrm{pH}$ adjustments were made with dilute sulphuric acid and sodium hydroxide solutions as required. A stock solution of thiocyanate was prepared by dissolving an appropriate amount of potassium thiocyanate in $100 \mathrm{ml}$ of water. Working solutions were prepared by successive dilutions. $\mathrm{H}_{2} \mathrm{SO}_{4}$ and $\mathrm{NaOH}$ solutions having different concentrations were used to study the $\mathrm{pH}$ dependence of thiocyanate-selective electrode.

\subsection{Membrane preparation and sensor construction}

A mixture of PVC and a plasticizer (dictylphtalate (DOP), 2-nitrophenyl octyl ether (NE)) to give a total mass of $60 \mathrm{mg}$ was dissolved in approximately $5 \mathrm{ml}$ of tetrahydrofuran and $1 \mathrm{ml}$ of nitrobenzene. To this mixture was added the electroactive material - $\left[\mathrm{Cr}_{3} \mathrm{O}\left(\mathrm{C}_{5} \mathrm{H}_{9} \mathrm{O}_{2}\right)_{6}\left(\mathrm{H}_{2} \mathrm{O}\right)_{3}\right] \mathrm{SCN}$ and 4,4'-bipyridine in stoechiometric ration 2:3 (synthesis in situ [12-14]). The solution was poured onto a glass dish (ca. $5 \mathrm{~cm}$ diameter) and allowed to dry at room temperature. A membrane (ca. $16 \mathrm{~mm}$ diameter) was cut and glued to the polished end of PVC tube by using a PVC (ca. 5\%) tetrahydrofuran solution. The $\mathrm{Ag} / \mathrm{AgCl}$ electrode and $10^{-1} \mathrm{M}$ of $\mathrm{SCN}^{-}+5 \cdot 10^{-3} \mathrm{M}$ of $\mathrm{KCl}$ solution were used as reference electrode and the internal filing solution, respectively.

The electrode was conditioned for $12 \mathrm{~h}$ in a $10^{-1} \mathrm{M}$ potassium thiocyanate solution, and stored in the same solution when is not in use. A silver/silver chloride electrode was used as an internal reference electrode.

\subsection{Potential measurements}

All measurement was made with a cell of the type:

$\mathrm{Ag} / \mathrm{AgCl}, \mathrm{KCl}\left(5 \cdot 10^{-3} \mathrm{M}\right) \mid$ internal filing solution $\left(10^{-1} \mathrm{M} \mathrm{SCN}^{-}\right) \mid \mathrm{PVC}$ membrane $\|$ tested solution $\| \mathrm{KCl}$ satd. $\mathrm{AgCl} / \mathrm{Ag}$. The performance of each electrode was investigated by measuring its potential in potassium thiocyanate 
solutions in the concentration range $1 \cdot 10^{-1}$ to $1 \cdot 10^{-7} \mathrm{M}$. Potential were measured using a $3310 \mathrm{JENWAY} \mathrm{pH} / \mathrm{mV}-\mathrm{meter}$. The performance of the electrode was investigated by measuring its potential in potasium thiocyanate solutions prepared in the concentration range $\left(10^{-1}-10^{-7} \mathrm{~mol} / \mathrm{L}\right)$ by gradual dilution of $0,1 \mathrm{~mol} / \mathrm{L} \mathrm{KSCN}$ stock standart solution. The solutions were stirred and potential readings recorded when they became stable. The data were plotted as observed potential versus the minus logarithm of the $\mathrm{SCN}^{-}$concentration.

\subsection{Sensor selectivity}

Potentiometric selectivity coefficients $\left(\mathrm{K}_{\mathrm{SCN}, \mathrm{X}}\right)$ were evaluated using the mixed solution method. The potential was measured for solutions of constant activity of the interfering ion (X) and varying activity of the primary ion $\left(\mathrm{SCN}^{-}\right)$. The obtained electromotive force values were plotted vs. the logarithm of the primary ion activity. The intersection of the extrapolated linear portions of this plot indicates the $\mathrm{a}_{\mathrm{SCN}}$ value that is to be used to calculate $\mathrm{K}_{\mathrm{SCN}, \mathrm{X}}$ from the following equation: $K \mathrm{SCN}, \mathrm{X}=a_{\mathrm{SCN}} /\left(a_{\mathrm{X}}\right)^{\mathrm{ZSCN} / Z \mathrm{X}}$ where ZSCN and ZX are the charges on $\mathrm{SCN}^{-}$and the interfering anion, respectively.

\subsection{Potentiometric titration of thiocyanate}

A thiocyanate membrane sensor based on the ionophore - trinuclear chromium(III) complex - as an indicator sensor and the $\mathrm{Ag} / \mathrm{AgCl}$ double junction reference electrode were used for monitoring the titration of thiocyanate solution with $\mathrm{AgNO}_{3}$. The sensor and reference electrode were immersed in an unknown $\mathrm{SCN}^{-}$test solution in $20 \mathrm{ml}$ beaker. The potential reading was recorded after each addition. The equivalence point was calculated from the sharp inflection at the equivalence point or from derivative curves.

\section{Result and discussion}

Recently trinuclear chromium(III) pivalates were investigated as ionophores in the membrane of the anionic sensors. The lipophilic complex cation can be combined with some inorganic and organic anions. We described electrodes selective to the presence of the perchlorate, salicylate and nitrate anions [12-14].

Therefore, using this type of chromium(III) complexes, we were prompted to study the response of a membrane to the presence of thiocyanate anions. The potentiometric response of ISE containing the ionophore $\left[\mathrm{Cr}_{3} \mathrm{O}\left(\mathrm{C}_{5} \mathrm{H}_{9} \mathrm{O}_{2}\right)_{6}\left(\mathrm{C}_{10} \mathrm{H}_{8} \mathrm{~N}_{2}\right)_{1,5}\right] \mathrm{SCN}$ synthesized in situ, was linear with a Nernstian slope of $57 \pm 2 \mathrm{mV} /-\log$ a $\left(\mathrm{SCN}^{-}\right)$and the detection limit, calculated as recommended by the IUPAC, was $5 \cdot 10^{-6} \mathrm{~mol} / \mathrm{L}$ (fig. 1).

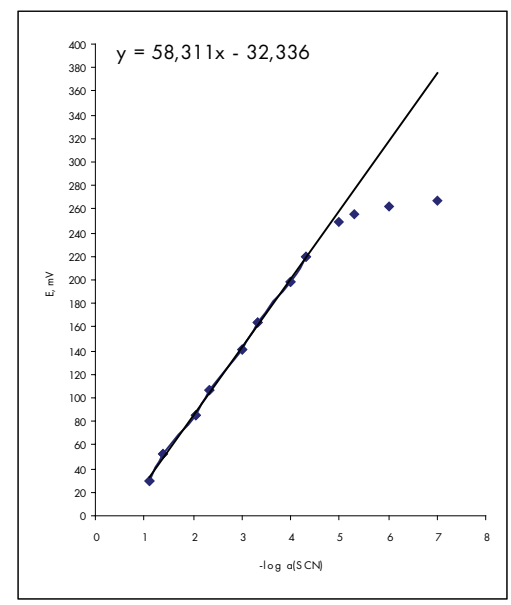

Fig. 1. Calibration graph for the electrode

The optimum equilibration time for the membrane electrode in the presense of $0,1 \mathrm{~mol} / \mathrm{L} \mathrm{KSCN}$ was $24 \mathrm{~h}$, after which it generated stable potential in contact with thiocyanate solutions. The evolution of the thiocyanate selective electrode slopes in time is presented in fig.2.

There was a little slope decrease in time, but it still remains, after 6 months of intensive use, in the analitycal useful range of $56-59 \mathrm{mV} / \mathrm{p}(\mathrm{SCN})$. The effect of $\mathrm{pH}$ of the test solution on the membrane electrode response was tested in the $\mathrm{pH}$ range $2,0-12,0$ at two $\mathrm{SCN}^{-}$concentrations $\left(10^{-2}\right.$ and $\left.10^{-3} \mathrm{~mol} / \mathrm{L}\right)$. The results presented in fig. 3 show that the potentials remain constant within $4,0-11,0 \mathrm{pH}$ range. 


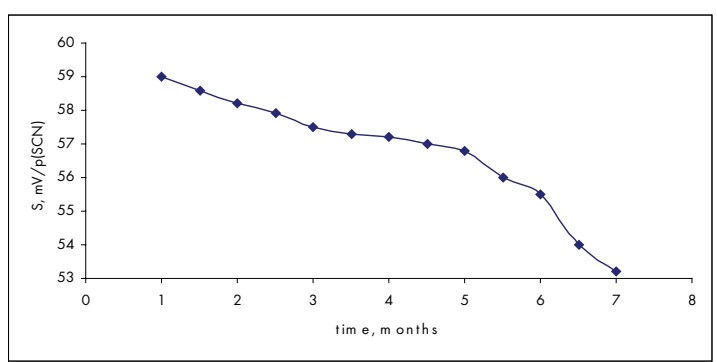

Fig. 2. Evolution of slope in time

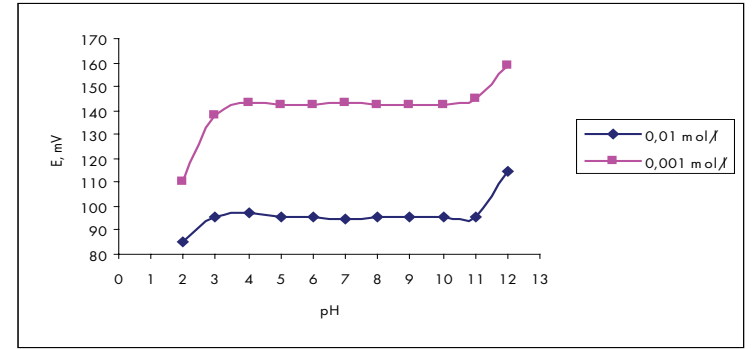

Fig. 3. The influence of the $\mathrm{pH}$ values on the electrode potential response

The variation of the potential at $\mathrm{pH}<4$ could be related to protonation of ionophore in the membrane phase which results in a loss of its ability to interact with $\mathrm{SCN}^{-}$ions. At high $\mathrm{pH}$ value, the $\mathrm{OH}^{-}$and $\mathrm{SCN}^{-}$anions are in a strong competition, the hydroxyl concentration grows and the potentiometric answer of the electrode can deviate from linearity. Similar results have been reported for other sensors [6].

One of the most important characteristics of any ion-selective electrode is the relative response for the primary ion over other ions that may be present in solution, which is expressed in terms of potentiometric selectivity coefficients. Potentiometric selectivity coefficients describing the preference of the membrane for an interfering ion $\mathrm{X}^{-}$relative to $\mathrm{SCN}^{-}$were determined by the mixed solutions method. Table 1 lists the potentiometric selectivity coefficients data of the sensor for several anions relative to $\mathrm{SCN}^{-}$.

Table 1

Electrode selectivity coefficients

\begin{tabular}{|c|c|c|c|c|c|c|c|c|c|c|c|}
\hline $\mathbf{X}$ & $\mathbf{I}^{-}$ & $\mathbf{C l O}_{\mathbf{4}}^{-}$ & $\mathbf{N O}_{\mathbf{3}}^{-}$ & $\mathbf{B F}_{\mathbf{4}}^{-}$ & $\mathbf{C O}_{\mathbf{3}}{ }^{2-}$ & $\mathbf{H P O}_{4}{ }^{2-}$ & $\mathbf{B r}$ & $\mathbf{F}^{-}$ & $\mathbf{C l}^{-}$ & $\mathbf{C H}_{\mathbf{3}} \mathbf{C O O}^{-}$ & $\mathbf{S O}_{\mathbf{4}}{ }^{-2}$ \\
\hline $\begin{array}{l}-\operatorname{logK} \\
\text { SCN/X }\end{array}$ & 1,58 & 2,04 & 2,16 & 2,53 & 3,23 & 3,47 & 3,80 & 4,07 & 4,10 & 4,18 & 4,55 \\
\hline
\end{tabular}

It is clear that the proposed electrode is selective to $\mathrm{SCN}^{-}$, and the selectivity sequence is: $\mathrm{SCN}^{-}>\mathrm{I}^{-}>\mathrm{ClO}_{4}^{-}>\mathrm{NO}_{3}^{-}>\mathrm{BF}_{4}^{-}>\mathrm{CO}_{3}{ }^{2-}>\mathrm{HPO}_{4}{ }^{2-}>\mathrm{Br}^{-}>\mathrm{F}^{-}>\mathrm{Cl}^{-}>\mathrm{CH}_{3} \mathrm{COO}^{-}>\mathrm{SO}_{4}{ }^{2-}-$ the main interfering anions were found to be iodide, perchlorate and nitrate.

The influense of the plasticizer nature on the parameters of the SCN-senzor were studied. Table 2 reveals that the parameters, like the slope, detection limit and $\mathrm{pH}$ range, are not influenced by the nature of this plasticizer.

Influence of the plasticizer nature on the parameters of the sensor

Table 2

\begin{tabular}{|c|c|c|c|}
\hline Plastisizer & $\begin{array}{c}\text { Slope, } \\
\mathbf{m V} / \mathbf{p a}\end{array}$ & $\begin{array}{c}\text { Detection } \\
\text { limit, } \mathbf{M}\end{array}$ & $\mathbf{p H}$ range \\
\hline NE & $57-58$ & $(4-7) \cdot 10^{-6}$ & $3-11$ \\
\hline DOP & $57-59$ & $(4-7) 10^{-6}$ & $3-11$ \\
\hline
\end{tabular}

The performances of a selection of different electrodes published in literature are shown in the Table 2. As it can be observed the parameters of the proposed electrode are comparable with of available thyocyanate-selective ones. Nevertheless the cost of electroactive material is chipper and it is more available that the complexes used in [2-11].

Table 3

Parameters of a selection of thiocyanate-selective electrodes

\begin{tabular}{|c|c|c|c|c|c|c|}
\hline Ionophore & $\begin{array}{c}\text { Concentration } \\
\text { range, mol/L }\end{array}$ & $\begin{array}{c}\text { Slope, } \mathbf{m V /} \\
\mathbf{d e c a d e}\end{array}$ & $\begin{array}{c}\text { Detection } \\
\text { limit, } \\
\mathbf{m o l} / \mathbf{L}\end{array}$ & $\begin{array}{c}\mathbf{p H} \\
\text { range }\end{array}$ & Lifetime & Reference \\
\hline $\begin{array}{c}5,10,15,20 \text {-tetrakis-(4- } \\
\text { methoxyphenyl)-porphyrin- } \\
\text { Co(II) }\end{array}$ & $1 \cdot 10^{-1}-1 \cdot 10^{-5}$ & 65,8 & $6,0 \cdot 10^{-6}$ & $3,0-9,5$ & 6 weeks & {$[2]$} \\
\hline $\begin{array}{c}\text { (octabromotetraphenylporphyrin } \\
\text { ato)manganese(III) chloride }\end{array}$ & $1-4,8 \cdot 10^{-7}$ & 58,3 & $3,2 \cdot 10^{-7}$ & & 3 months & {$[3]$} \\
\hline $\begin{array}{c}\text { N, N'-ethylene-bis(4- } \\
\text { methylsalicylidineiminato) } \\
\text { nickel(II) }\end{array}$ & $1 \cdot 10^{-1}-1 \cdot 10^{-6}$ & 58,9 & $3,1 \cdot 10^{-7}$ & $3,5-8,5$ & 3 months & {$[4]$} \\
\hline
\end{tabular}




\begin{tabular}{|c|c|c|c|c|c|c|}
\hline $\begin{array}{c}\text { crown ether-cetyltrimethyl } \\
\text { ammonium }\end{array}$ & $1 \cdot 10^{-1}-1 \cdot 10^{-6}$ & 57,6 & $3,0 \cdot 10^{-7}$ & $3,8-9,2$ & 6 weeks & {$[5]$} \\
\hline $\begin{array}{c}5,10,15,20 \text {-tetrakis(2,4,6- } \\
\text { trimethylphenyl)- } \\
\text { porphyrinatomanganese(III) } \\
\text { chloride }\end{array}$ & $1 \cdot 10^{-1}-2 \cdot 10^{-7}$ & 58,7 & $1,3 \cdot 10^{-6}$ & $2,0-10,0$ & 3 months & {$[6]$} \\
\hline $\begin{array}{c}{\left[\text { Cobalt (Salpen) }\left(\mathrm{PBu}_{3}\right) \mathrm{ClO}_{4}\right.} \\
\cdot \mathrm{H}_{2} \mathrm{O}\end{array}$ & $1 \cdot 10^{-1}-1 \cdot 10^{-6}$ & 59,05 & $8,0 \cdot 10^{-7}$ & $2,8-9,8$ & 14 weeks & {$[7]$} \\
\hline $\begin{array}{c}N, N^{\prime} \text {-bis-(benzaldehyde)-glycine } \\
\text { metallic complexes }\end{array}$ & $1 \cdot 10^{-1}-9 \cdot 10^{-7}$ & 57,6 & $7,0 \cdot 10^{-7}$ & $4,0-7,0$ & & {$[8]$} \\
\hline $\begin{array}{c}\text { macrotricyclic binuclear Cu(II)- } \\
\text { Schiff base complex }\end{array}$ & $1 \cdot 10^{-1}-1 \cdot 10^{-7}$ & 58,9 & $3,1 \cdot 10^{-8}$ & $3,0-8,0$ & 2 months & {$[9]$} \\
\hline rhodium(II) phthalocyanine & $1 \cdot 10^{-1}-1 \cdot 10^{-6}$ & 56,3 & $7,9 \cdot 10^{-7}$ & 6,0 & 2 months & {$[10]$} \\
\hline $\begin{array}{c}\text { copper(II) bis(benzoylacetone) } \\
\text { propylenediimine complex }\end{array}$ & $1 \cdot 10^{-1}-8 \cdot 10^{-7}$ & 57,4 & $7,4 \cdot 10^{-7}$ & $1,7-11,5$ & & {$[11]$} \\
\hline
\end{tabular}

\section{Analytical application}

The proposed sensor was successfully used as an indicator electrode in the potentiometric titration of SCNsolution with $\mathrm{Ag}^{+}$. Results of the titration are shown, the amount of $\mathrm{SCN}^{-}$ion in solution can be accurately determined with the electrode. A very good inflection point, showing perfect stoichiometry, was observed in the titration plot (fig. 4).

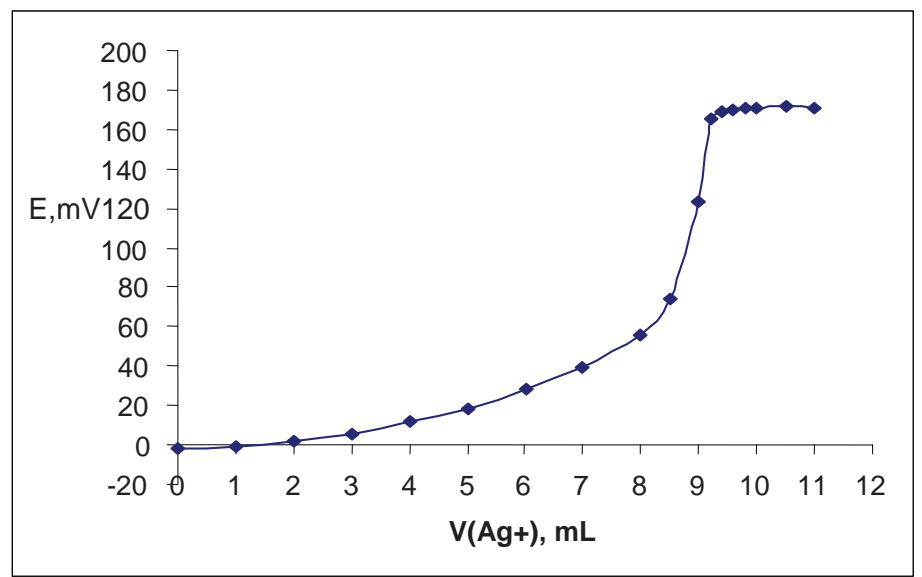

Fig. 4. Potentiometric titration curve of $10,0 \mathrm{ml}^{10^{-2}} \mathrm{~mol} / \mathrm{l} \mathrm{SCN}$ with $1,08 \cdot 10^{-2} \mathrm{~mol} / \mathrm{l} \mathrm{AgNO}_{3}$, using the $\mathrm{SCN}^{-}$selective electrode based on trinuclear chromium(III) pivalate

This electrode was additionally applied to the direct determination of the $\mathrm{SCN}^{-}$ions in different sample solutions. The resulting data of Table 4 indicate that the accuracy of the $\mathrm{SCN}^{-}$ion detection in different sample solutions is almost quantitative.

The SCN- ions recovery from binary mixtures by the proposed electrode

Table 4

\begin{tabular}{|c|c|c|}
\hline $\mathbf{S C N}, \mathbf{m o l} / \mathbf{L}$ & $\begin{array}{c}\text { Added anion, } \\
\mathbf{m o l} / \mathbf{L}\end{array}$ & Recovery, $\mathbf{~ m o l} / \mathbf{L}$ \\
\hline $10^{-2}$ & $\mathrm{SO}_{4}^{2-}, 10^{-2}$ & $(1,03 \pm 0,03) \cdot 10^{-2}$ \\
\hline $10^{-2}$ & $\mathrm{CH}_{3} \mathrm{COO}^{-}, 10^{-3}$ & $(0,99 \pm 0,04) \cdot 10^{-2}$ \\
\hline $10^{-2}$ & $\mathrm{Cl}, 10^{-3}$ & $(1,03 \pm 0,04) \cdot 10^{-2}$ \\
\hline $10^{-2}$ & $\mathrm{HPO}_{4}^{2-}, 10^{-4}$ & $(0,99 \pm 0,05) \cdot 10^{-2}$ \\
\hline $10^{-2}$ & $\mathrm{HCO}_{3}^{2-}, 10^{-4}$ & $(1,02 \pm 0,01) \cdot 10^{-2}$ \\
\hline $10^{-2}$ & $\mathrm{NO}_{3}^{-}, 10^{-4}$ & $(0,99 \pm 0,05) \cdot 10^{-2}$ \\
\hline
\end{tabular}

Results are based on three measurements

\section{Conclusion}

A novel electrode has been developed based on trinuclear chromium(III) pivalate as ionophore in dictylphtalate or 2-nitrophenyl octyl ether plasticized PVC membranes. The electrode exhibited good potentiometric response characteristics to thiocyanate and was applied as an indicator electrode in the potentiometric titration of the $\mathrm{SCN}^{-}$ solution with $\mathrm{AgNO}_{3}$. 


\section{References}

[1]. MEBERG A., MARSTEIN S. Smoking during pregnancy: effects on the fetal thyroid function. Acta Paediatrica Scandinavica, 1986, 75(5), p. $762-766$.

[2]. VLASICI, D., FAGADAR-COSMA, E., BIZEREA-SPIRIDON, O. A new composition for Co(II)-porphirinbased membranes used in thiocyanate-selective electrodes. Sensors 2006, 6, p. 892-900.

[3]. SHAMSIPUR, M., KHAYTIAN, G., TANGESTANINEJAD, S. Thiocyanate-selective membrane electrode based on (octabromotetraphenylporphyrinato)manganese(III) chloride. Electroanalysis, V. 11, Issue 18, 1999, p. $1340-1344$.

[4]. MAZLOUM, M., JAMSHIDPOOR, M., NAEIMI, H., MORADI, L. Thiocyanate ion-selective PVC membrane electrode based on N, N'-ethylene-bis(4-methylsalicylidineiminato)nickel(II). Analytical Sciences, Vol. 22 (2006), No. 9, p. 1221.

[5]. ARVAND, M., ZANJANCHI, M., HEYDARI, L. Novel Thiocyanate-selective membrane sensor based on crown ether-cetyltrimethyl ammonium thiocyanate ion-pair as a suitable ionophore. Sensors, V. 122, Issue 1, March 2007, p. $301-308$.

[6]. POURSABERI, T., SALAVATI-NIASSARI, M., KHODABAKHSH, S. A selective membrane electrode for thiocyanate ion based on a copper-1,8-dimethyl-1,3,6,8,10,13-azacyclotetradecane complex as ionophore. Analytical Letters, V. 34, Issue 15 (2001), p. 2621-2632.

[7]. SHOKROLlAHI, A., GHAEDI, M., GHAEDI, H. Thiocyanate-selective membrane electrode based on cobalt(III) Schiff base as a charge carrier. International Journal of Environmental Analytical Chemistry, V. 88, Issue 12, 2008, p. 841-856.

[8]. CHAI, Y., DAI, I., YUAN, R. Highly thiocyanate-selective membrane electrodes based on the $N, N^{\prime}$-bis(benzaldehyde)-glycine copper(II) complex as a neutral carrier. Desalination, V. 180, Issue 1-3, 2005, p. 207215.

[9]. HYUNG, R., HYO, K., SEUNGWON, J. Improved Thiocyanate-Selective Electrode Based on Tetra(trimethylphenyl)-porphyrinato Manganese(III) Chloride: The Electronic and pH Effects. Bull. Korean Chem. Soc. 2004, Vol. 25, No. 10, p. 1484-1488.

[10]. SHAHROKHIAN, S., JANNATREZVANI, M., KHAJENSHARIFI, H. Rhodium(II) phthalocyanine as a selective carrier in thiocyanate-selective membrane electrode. Analytical letters, V. 38, Issue 8, 2005, p. 1221-1235.

[11]. EZAEI, B., MEGHDADI, S., NAFISI, V. HIGHLY THIOCYANATE-SELECTIVE MEMBRANE ELECTRODE BASED ON THE BIS(BENZOYLACETONE) PROPYLENEDIIMINE COPPER(II) COMPLEX. Annali di chimica, 2007, vol. 97, n¹1-12, p. 1191-1205.

[12]. REVENCO, M., MARTIN, M., WAELL, A. A. D. Nitrate-selective electrodes based on the trinuclear chromium(III) pivalates. Chemistry journal of Moldova, V. 3, No. 1, 2008, p. 44-47.

[13]. REVENCO, M., MARTIN, M. Senzor potențiometric pentru determinarea percloraților. Anale ştiințifice ale Universității de Stat din Moldova, seria "Ştiințe chimico-biologice”, Chişinău 2006, p. 480-484.

[14]. REVENCO, M., MARTIN, M., GAVRILUȚA A., WAELL, A. A. D. Senzor potențiometric salicilat-senzitiv pe bază de pivalaţi trinucleari ai cromului(III). Studia Universitatis, ştiințe ale naturii, Nr. 2(12), 2008, p.146-149. 